\title{
MENGHADIRKAN MODEL PEMBELAJARAN SOSIODRAMA UNTUK MENINGKATKAN KE AKTIFAN BELAJAR SISWA
}

\author{
Indah Purwanti \\ Program Studi Pendidikan Sejarah FKIP Universitas Lambung Mangkurat Banjarmasin \\ Email : indahpurwanti488@gmail.com
}

\begin{abstract}
Abstrak : Mata pelajaran Sejarah memiliki arti strategis dalam pembentukan watak dan peradaban bangsa yang bermartabat serta dalam pembentukan manusia Indonesia yang memiliki rasa kebangsaan dan cinta tanah air. Dengan karakter materi yang dinyatakan dalam Peraturan Mendiknas, pendidikan sejarah, baik sebagai bagian IPS mau pun sebagai mata pelajaran merupakan salah satu mata pelajaran yang memiliki potensi besar dalam mengembangkan pendidikan karakter. Melalui pelajaran sejarah peserta didik dapat melakukan kajian mengenai apa dan bila, mengapa, bagaimana, serta akibat apa yang timbul dari jawaban masyarakat bangsa di masa lampau tersebut terhadap tantangan yang mereka hadapi serta dampaknya bagi kehidupan pada masa sesudah peristiwa itu dan masa kini.

Bagaimana cara saat kita saat ini membuat siswa itu aktif dengan menghadirkan suasana belajar yang sedikit berbeda dari biasanya dan terkesan menarik. Bagaimana cara saat ini kita membangkitkan lagi rasa nasionalisme anak muda untuk tidak melupakan sejarah. Dengan adanya model pembelajaran menggunakan teknik sosiodrama ini pula dapat diterapkan disekolah-sekolah pada mata pelajaran sejarah. Mereka dapat memepelajari dan memaikan sosok tokoh Pahlawan ataupun cerita rakyat yang berkaitan dengan sejarah. Keberhasilan proses pembelajaran bergantung kepada penggunaan sumber dan media pembelajaran yang sesuai. Jika sumber dan media yang dipilih dan dipersiapkan dengan tepat dan hati-hati dapat memenuhi antara lain : menimbulkan motivasi positif peserta didik, melibatkan peserta didik, menjelaskan dan menggambarkan isi subjek, dan menggambarkan kerja individual. Maka kedudukan media dalam pembelajaran tidak dapat dianggap sepele. Perlu diperhatian bahwa materi ajar yang berbeda memerlukan media dan sumber pembelajaran yang berbeda pula.
\end{abstract}

Kata kunci : sosiodrama dan aktif 


\section{PENDAHULUAN}

Apa yang dilakukan dalam kegiatan pendidikan dalam membangun kualitas warganegara dan bangsa dapat dilihat dari kebijakan, perencanaan dan pelaksanaan kurikulum. Kebijakan kurikulum terus menerus dikembangkan untuk menjawab perubahan yang terjadi di masyarakat dan bangsa. Perubahanperubahan di masyarakat terjadi dari waktu ke waktu sesuai dengan dinamika kehidupan masyarakat dan bangsa sebagai konsekuensi dari perkembangan kehidupan sosial budaya- politik-ekonomi-agama, ilmu dan pengetahuan, teknologi. Dengan adanya teknologi dan sumber informasi yang digunakan sebagai langkah untuk melatatih ke aktifan siswa, karena hal itu dapat sangat berpengaruh. Perkembangan pendidikan di Nusantara dapat dikatakan mengalami titik balik dengan adanya kebijakan pendidikan politik etis, orang-orang bumiputera harus diperkenalkan kebudayaan dan pengetahuan barat, sehingga pemerintah Belanda banyak mendirikan sekolah-sekolah berorientasi barat. Secara tidak langsung pengaruh politik etis terutama bidang pendidikan yaitu memberikan dampak positif bagi muncul kaum terdidik dan pergerakan di indonesia. Fakta sejarah tersebut menunjukkan bahwa pendidikan berperan dalam membuka wawasan dan memperkaya pemikiran para tokoh pendiri bangsa dalam memperjuangkan bangsa. Dengan demikian bahwa pendidikan mempunyai keterkaitan yang sangat besar dengan Nasionalisme Indonesia (Heri Susanto, 2016).

Pembelajaran sejarah yang baik akan membentuk pemahaman sejarah. Pemahaman sejarah merupakan kecenderungan berfikir yang merefleksikan nilai-nilai positif dari peristiwa sejarah dalam keidupan sehari-hari, sehingga kita menjadi lebih bijak dalam melihat dan memberikan respon terhadap berbagai masalah kehidupan. Pemahaman sejarah memberi petunjuk kepada kita untuk melihat serangkaian peristiwa masa lalu sesuai dengan jiwa jamannya, akan tetapi memiliki sekumpulan nilai edukatif terhadap kehidpan sekaran dan akan datang (Heri Susanto,2014).

Keberhasilan proses pembelajaran bergantung kepada penggunaan sumber dan media pembelajaran yang sesuai. Jika sumber dan media yang dipilih dan dipersiapkan dengan tepat dan hati-hati dapat memenuhi antara lain : menimbulkan motivasi positif peserta didik, melibatkan peserta didik, menjelaskan dan menggambarkan isi subjek, dan menggambarkan kerja individual. Maka kedudukan media dalam pembelajaran tidak dapat dianggap sepele. Perlu diperhatian bahwa materi ajar yang berbeda memerlukan media dan sumber pembelajaran yang berbeda pula (Heri Susanto,2019).

\section{MODEL PEMBELAJARAN SOSIODRAMA UNTIK MENINGKATKAN KE AKTIFAN BELAJAR SISWA}

Sosiodrama adalah metode pembelajaran bermain peran untuk memecahkan masalah-masalah yang berkaitan dengan fenomena sosial, permasalahan yang menyangkut hubungan antara manusia seperti masalah kenakalan remaja, narkoba, gambaran keluarga 
yang otoriter, dan lain sebagainya. Sosiodrama digunakan untuk memberikan pemahaman dan penghayatan akan masalah-masalah sosial serta mengembangkan kemampuan siswa untuk memecahkannya. Berdasarkan beberapa defenisi tersebut dapat ditarik benang merah bahwa metode pembelajaran sosiodrama adalah model pembelajaran bermain peran dengan mendramatisasi kehidupan nyata atau konflik yang belum terselesaikan dan sistem sosial yang membentuk kita secara individu dan kolektif. Dalam proses pembelajaran ini menggunakan metode sosiodrama juga memerlukan suatu media yang menunjang agar peserta didik bisa memerankan suatu pemarsalahan sosial dan bisa memberikan argumentasi yang baik. Menceritakan tentang fenomena sejrah, tokoh pahlawan, atau sebuah peristiwa yang tejadi dulu. Pembelajaran dengan metode ini dimulai dengan menetapkan tujuan yang hendak dicapai. Pada tahap ini guru menyampaikan tujuan pembelajaran yang hendak dicapa, dengan siswa menyimak penjelasan dari guru (Ketut Ayu, dkk, 2014).

Sosiodrama merupakan salah satu teknik dalam bimbingan kelompok yaitu role playing atau teknik bermain peran. Menurut Djamur dan Muh. Surya (2001: 109), sosiodrama dipergunakan sebagai salah satu teknik untuk memecahkan masalah-masalah sosial dengan melalui kegiatan bermain pran. Di dalam sosiodrama ini seseorang akan memerankan suatu peran tertentu dari situasi masalah sosial. Sosiodrama merupakan dramatisasi dan persoalan-persoalan yang dapat timbul dalam pergaulan dengan orang lain, tingkat konflik, konflik yang dialami dalam pergaulan sosial (Wingkel, 2004: 470). (Romaliah,1999: 104) berpendapat bahwa sosiodrama adalah permainan peran yang ditujukan untuk memecahkan masalah sosial yang timbul dalam hubungan anatar manusia. Jadi teknik sosiodrama adalah teknik bermain peran dalam rangka untuk memecahkan masalah sosial yang timbul dalam hubungan interpesonal (rasa cemburu, dilema dll) yang dilakukan dalam kelompok (Daud: 2009).

Ke aktifan belajar terdiri dari kata kreativitas dan kata belajar. "Keaktifan memiliki kata dasar aktif yang berarti giat dalam belajar atau berusaha (Rahmi, 2004). Keaktifan belajar berarti suatu usaha atau kerja yang dilakukan dengan giat dalam belajar. Ciri-ciri keaktifan belajar mencakup : 1) keinginan dan keberanian menampilkan perasaan, 2) keinginan dan keberanian serta kesempatan berprestasi dalam kegiatan baik persiapan, proses dan kelanjutan belajar, 3) penampilan berbagai usaha dan kreativitas belajar mengajar dalam menjalami dan menyelesaikan kekeluasaan melakukan hak tersebut di atas tanpa tekanan guru atau pihak lain. Faktor-faktor yang mempengaruhi keaktifan belajar, yakni : 1) Stimulasi belajar, 2) prhatian dan motivasi, 3) respon yang dipelajarinya, 4) penguatan, 5) pemakaian dan pemindahan. Guru merupakan penanggung jawab kegiatan proses pembelajaran di dalam kelas. Sebab gurulah yang langsung memberikan kemungkinan bagi para siswa belajar dengan efektif melalui pemebelajaran yang dikelolanya. Kehadiran guru dalam proses belajar mengajar atau penagajaran masih tetap memegang peranan penting. Peranan guru dalam proses belajar mengajar belum dapat 
digantikan oleh mesin, radio, tape recorder ataupun komputer yang paling modern sekalipun.

\section{TUJUAN DAN LANGKAH-LANGKAH MENGUNAKAN MODEL SOSIODRAMA}

a. Tujuan Sosiodrama

Tujuan sosiodrama antara lain sebagai beriku :

1. Agar anak didik mendapatkan keterampilan sosial sehingga diharapkan nantinya tidak canggung menghadapi situasi sosial dalam kehidupan sehari-hari.

2. Menghilangkan rasa kurang percaya diri atau tidak pede saat berada di depan banyak orang.

3. Mendidik dan mengembangkan kemampuan diri untuk mengemukakan pendapat didepan banyak orang.

4. Membiasakan diri untuk sanggup menerima dan menghargai pendapat orang lain.

b. Langkah-Langkah Sosiodrama.

Menurut Guntur Tarigan dalam (Waluyo,2003: 55) ada tiga langkah yang harus dilalui jika seseorang mau mementaskan atau menulis sosiodrama yaitu :

1) Mengemukakan suatu masalah.

2) Mendramtisasikan masalah.

3) Mendiskusikan hasil dramatisasi.

Menurut Torrance dalam (Waluyo,2001: 190) mengemukakan delapan langkah untuk mengefektifkan sosiodrama sebagai sarana siswa untuk menghadapi problem dan tantangan, yaitu sebagai berikut :

1) Menetapkan problem.

2) Mendeskripsikan situasi konflik.

3) Pemilihan pemain (casting character).

4) Memberikan penjelasan dan pemanasan bagi aktor dan pengamat.

5) Memerankan situasi tersebut.

6) Memotong adegan (jika aktor meninggalkan peran dan tidak dapat diteruskan atau dapat juga membuat kesimpulan).

7) Mendiskusikan dan menganalisis situasi, kelakuan dan gagasan yang diproduksi.

8) Menyusun rencana untuk testing lebih lanjut atau implementasi.

Berdasarkan pendapat-pendapat diatas dan disesuaikan dengan materi yang ada, langkah metode sosiodrama yang peneliti gunakan yaitu :

1) Menetapkan materi bahan yang akan dibuat sosiodrama.

2) Setelah materi, ditetapkan pola pokok bahasan mana saja yang akan digunakan pada siklus I dan siklus II.

3) Membuat rancangan skenario sosiodrama tersebut.

4) Melakukan kajian ulang terhadap scenario atau teks drama tersebut. 
5) Menjelaskan atau memberikan pengarahan kepada siswa tentang sosiodrama dan apa saja yang akan mereka lakukan.

6) Menentukan pemain yang akan bermain dalam sosiodrama tersebut

7) Memainkan sosiodrama tersebut.

8) Guru dan siswa dapat memberikan komentar, kesimpulan dan catatan jalannya sosiodrama tersebut.

\section{KELEBIHAN DAN KEKURANGAN MODEL PEMBELAJARAN SOSIODRAMA}

a. Kelebihan Metode Sosiodrama

Beberapa kelebihan metode sosiodrama antara lain :

1) Kerjasama antar pemain dapat ditumbuhkan dan dibina dengan sebaik-baiknya.

2) Murid memperoleh kebiasaan untuk menerima dan membagi tanggung jawab dengan sesamanya.

3) Bahasa lisan murid dapat dibina menjadi bahasa yang baik agar mudah dipahami orang lain (Khoirrunis: 2011).

4) Murid akan terlatih untuk berinisiatif dan berkreatif pada waktu main drama para pemain dituntut untuk mengemukakan pendapatnya sesuai dengan waktu yang tersedia.

5) Bakat yang terdapat pada murid dapat dipupuk sehingga dimungkinkan akan muncul atau tumbuh bibit seni drama dari sekolah. Jika seni drama mereka dibina dengan baik memungkinkan besar mereka akan menjadi pemain yang baik kelak.

b. Kelemahan Metode Sosiodrama Selain mempunyai kelebihan metode ini juga memiliki kelemaha. Beberapa kelemahan dalam metode ini menurut (Muttoharoh,2010) anatar lain :

1) Sosiodrama dan bermain peranan memerlukan waktu yang relatif panjang/banyak

2) Memerlukan keaktivitas dan daya kreasi yang tinggi dari pihak guru maupun murid. Dan ini tidak semua guru memilikinya

3) Kebanyakan siswa yang ditunjuk sebagai pemeran merasa malu untuk memerankan suatu agenda tertentu.

4) Apabila pelaksanaan sosiodrama dan bermain pemeran mengalami kegagalan bukan saja dapat memberi kesan kurang baik, tetapi sekaligus berarti tujuan pengajaran tidak tercapai.

5) Tidak semua materi pelajaran dapat disajikan melalui metode ini.

Model pembelajaran sosiodrama ini jika dilakukan dengan baik dan sungguhsungguh maka akan mengahsilkan suasana belajar yang jauh lebih menarik dan bagus. Maka itu sendiri akan membuat siswa lebih menyukai mata pelajaran sejarah sendiri, dengan adanya model belajar sosiodrama juga akan meningkatkan ke aktifan belajar 
siswa yang biasanya malas-malasan. Jika hal ini akan dilakukan maka sebelumnya guru akan memberikan penjelasan dan pemahaman terlebih dahulu. Kemampuan siswa dapat dinilai dari peran yang kita berikan kepadanya, karena dala model pembalajaran ini siswa akan mendapat peran yang tidak terduga-duga sebelumnya.

\section{PENUTUP}

Model pembelajaran sosiodrama mengajarkan kepada siswa tentang adanya kerjasama dan saling bergotong royong. Bukan hanya itu dengan model pembelajaran ini siswa bisa merasakan suasana kelas yang tidak biasa dan akan membuat siswa tidak bosan dengan adanya model ini kita menghadirkan suasana baru. Siswa juga memilih ddan menentukan tema apa yang ingin dimainkan dengan menyiapkan para tokoh pemain. Jadi dalam kelompok semua aktif dan mengikuti proses pembelajaran sosiodrama ini walaupun untuk memainkannya membetuhkan waktu yang cukup lama untuk sebuah pertujunkan yang menarik, dengan bertukar peran siswa juga bisa sambil belajar mengenai tokoh yang diperankan itu.

Untuk meningkatkan ke aktifan belajar siswa model pembelajaran ini bisa dijadikan alternatif yang bagus karena dalam model ini semua siswa akan aktif dan semua akan memerankan tokoh yang sudah dipilih. Bahkan menggunakan model ini bisa menambah pengetahuan mereka, apabila peran yang dimaikan adalah tokoh pahlawan ataupun menampilkan sebuah peristiwa sejarah dengan model ini siswa juga sambil mempelajari dan sekaligus menjadi ilmu pengetetahuan.

\section{DAFTAR PUSTAKA}

Nuraeni, Dewi, 2012. Penerapan Metode Pembelajaran Sosiodrama Untuk Meningkatkan Motivasi Belajar IPS Materi Sekitar Proklamasi Kemerdekaan Pada Siswa Kelas V SDN Kayuapak 01 Polokarto Sukoharjo. Dikutip pada 31 Maret 2020. Diakses di: http://google.shcolar.com/

Susanto, Heri, 2014. Seputar Pembelajaran Sejarah (Isu, Gagasan dan Strategi). Aswaja Pressindo Yogyakarta. Dikutip pada 31 Maret 2020. Diakses di: http://google.shcolar.com/

Susanto, H, 2016. Pendidikan dan Kesadaran Nasionalisme. Seminar Internasional Pendidikan Berbasis Nilai-Nilai Kebangasaan, Universitas Lambung Mangkurat. Dikutip pada 7 April 2020. Diakses di: http://google.scholar.com/

Suanto, H. \& Akmal, Helmi. 2019. Media Pembelajaran Sejarah Era Teknolgi Informasi (Konsep Dasar, Prinsip Aplikatif, Dan Perancangannya). Program Studi Pendidikan Sejarah Fakultas Keguruan dan Ilmu Pendidikan Universitas Lambung Mangkurat. Dikuti pada 31 Maret 2020. Diakses di : http://google.shcolar.com/ 
Ayu, Ketut \& dkk, 2014. Pengaruh Metode Sosiodrama Berbantuan Cerita Rakya Terhadap Keterampilan Berbicara Siswa Kelas V SD. Jurnal Mimbar PGSD Universitas Pendidikan Ganesha Jurusan PGSD, Volume 2, No. 1 Tahun 2014. Dikutip Pada 8 April 2020. Diakses di : http://google.shcolar.com/

Miftahul, Jannah. \& Prasetyo, Bambang. Pendekatan Kuantitatif. Dikutip pada 7 April 2020. Diakses di : http://google.shcolar.com/

Hardini, Tri, 2015. Peningkatan Keaktifan dan Hasil Belajar Siswa Dalam Pembelajaran PPKN Melalui Metode Sosiodrama Dikelas 5 SD Tlompakan 01 - Tuntang. Dikuti pada 31 Maret 2020. Diakses di: http://google.shcolar.com/ 